\title{
Development Of Self Construction Animation Software To Improve The Quality Of Science Instruction In Junior High School
}

\author{
Diana Rochintaniawati \\ International Program on Science Education \\ Faculty on Mathematics and Science Education \\ UPI Indonesia \\ dianarochintaniawati@upi.edu
}

\author{
Rika Rafikah \\ International Program on Science Education \\ Faculty on Mathematics and Science Education \\ UPI Indonesia \\ rikarafikah@upi.edu
}

\author{
Yayan Sanjaya \\ International Program on Science Education \\ Faculty on Mathematics and Science Education \\ UPI Indonesia \\ Yayan229@yahoo.com
}

\begin{abstract}
This paper reports the result of study on development, implementation and evaluation of animation construction for integrated science teaching. The method of the study was research and development $(R \& D)$ consisted of two years research. The first year study was the development of animation resulted in topics of environment, energy, exploding candy and movement animations. In the second year study, the animation was implemented in three classrooms involving students from second year of secondary schools. Evaluation addressed by knowledge test and students' questionnaire. The knowledge test resulted in a value of $\mathrm{N}$ gain 0.43 mean that the improvement of students' understanding of science concept in a medium category. Weak experiment resulted in $t$ score 2.926 showed the fulfillment of mastery learning. Furthermore, student opinions about the animation were positive
\end{abstract}

\section{Keywords - Self Construction Animation, Integrated science}

\section{INTRODUCTION}

Globalization atmosphere has now becoming important for Indonesian society. One of the indicators of globalization is the use of technology that influences shift to the more modern living.

Curriculum 2013 supports teacher to use ICT in science teaching learning. The availability of computer provides by government in most Junior High School, makes the use of computer based media becoming more possible for science teaching. The research on ICT in science teaching has been done widely around the world. The principle of teaching by using animation make teacher possible to run students centre learning in order students to be able to exercise their thinking skill and problem solving skill [1]. This study aims to develop teaching media that provide opportunity to student to construct their own animation by using software.

Media give contribution to instructional process that can help student for their own learning. Computer can be used as teaching media. There are some supportive arguments to the computer use for students learning: experience, motivation, improving teaching and learning process, provide authentic content, do not rely on sole source, wider interaction, more personal and global understanding [2]. In science teaching, computer can be used to make abstract concepts to be more concrete. The use of computer is an effective in helping student to understand microscopic concepts [1].

Computer as teaching media, specifically animation is also can be used to replace laboratory activities that may dangerous or expensive if it is done by real laboratory activity [3]. Animation can be constructed through creative system with changing the objects or constructing the objects to produce illusion or movement [4]. Animation and simulation help student to understand difficult concept related to the complex science concepts. Visualization in animation which was designed and used effectively can help student to shape perception and understanding in a real context [5]. The use of animation in teaching involve student to the virtual world where they apply their knowledge and thinking skill in virtual situation [1]. The involvement of animation can also improve students' motivation in learning science as simulation is more effective form tutorial and test item exercise. Simulation can improve students' motivation, learning transfer, efficiency, flexibility besides secure and controlled feeling [4]. 


\section{RESEARCH METHOD}

Method used in the study was Research and Development (R\&D). The study involved two years research. The first year research was development of animation began with identification to the concepts of physics, biology and chemistry in 2013 curriculum which was followed by integration of science topics and development of stroryboard. Development of the animation utilized Flash program.

The second year of study involved the implementation of the animation in three classroom from 2 schools. The evaluation of the animation and the teaching was carried out by using knowledge test and students' questionaire. Weak experimental Pre test and post test design was adreesed to measure students' understanding improvement and students' mastery learning.

\section{RESULTS AND DISCUSSION}

The first year study resulted in story board and animation for the topics of: environment, energy, exploding candy and movement. Below are example of storyboard and animation

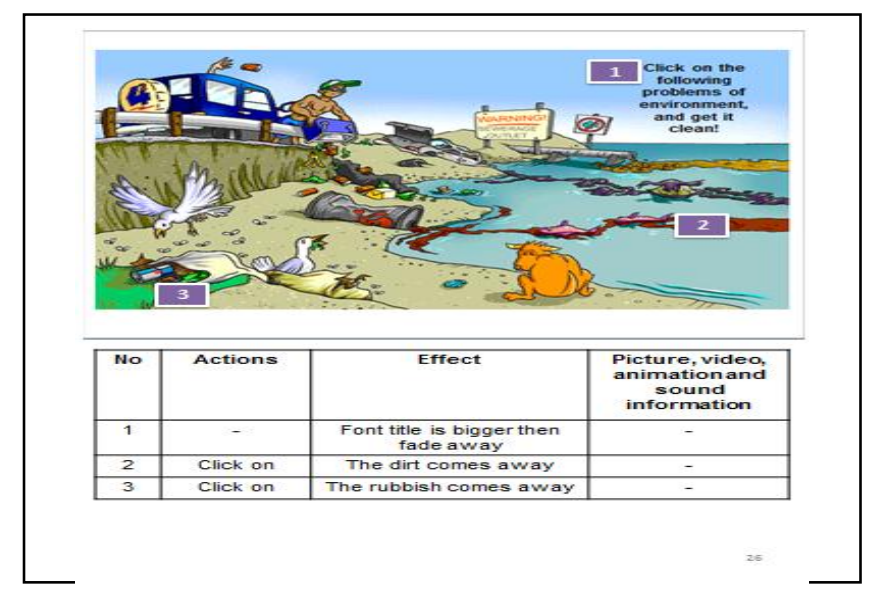

Fig. 1. Storyboard

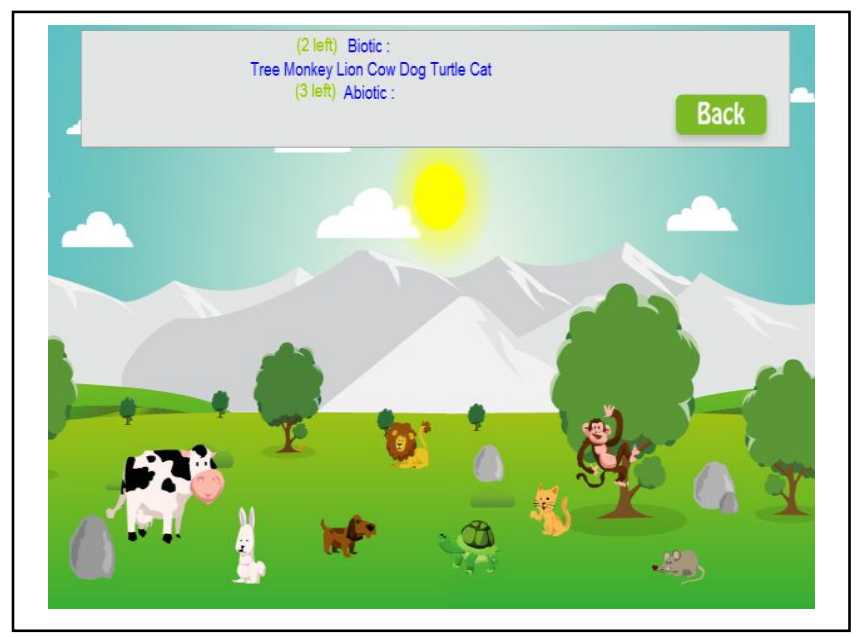

Fig 2. Animation
External judgment was done by media expert and teachers resulted that the animation is in good category. The knowledge test was carried out in two classroom of International school and one classroom of public school. Table 1 showed data taken from 3 classes.

\section{TABLE I. RESULT OF KNOWLEDGE TEST}

\begin{tabular}{|c|c|}
\hline Component & Value \\
\hline $\mathrm{N}$ & 48 \\
\hline Pre test Average & 65.94 \\
\hline Post test Average & 81.72 \\
\hline Gain & 14.80 \\
\hline N Gain & 0.43 (medium) \\
\hline
\end{tabular}

The knowledge test resulted in normalized gain 0.43 . The score indicated that the improvement of students' understanding was in a medium category. The significant test using weak experiment by comparing with mastery learning (score 70) resulted the value of $t$ test 2.926 which indicated that the self construction animation can improve students' understanding to the concept of energy, acid and base, human digestive system, ecology and movement.

Students and teachers respond to the animation measured by questionnaire. Positive respond was given from both students and teachers. They stated that the picture of animation is interesting. The concept is easily understood and can simplify complex concepts. Furthermore, they also said that the font used in animation is suitable for readers.

Based on the result of the study it can be concluded that self construction animation developed in the study was excellence in improving the quality of science instruction in term of cognitive aspects or students' understanding to the science concepts. Using media in flash program which has characteristic students' centered learning can help teacher to be more efficient in involving students in teaching learning process [6]. The increasing of students' motivation in learning gives benefit to teacher to ask students to be more involved in studying the content. Furthermore, variation profile of animation make students more interested to learn the content. Flash animation in learning can help student to understand dynamic phenomena if the animation provide in simple, clear and entertaining explanation of the information [7]. The contrary, if the animation provide simple information to be more complicated it will make student confuse [8]. Learners will face difficulty in fully constructing the concept, and resulted in gaining segmented information. Therefore it is important to consider the worthiness which includes both graphics and content when the media is developed.

Flash animation media in science teaching improve students' motivation to the concept, mostly when in the animation provides cartoon characters [9]. As the result teacher can have effective teaching. The study also showed that animation can improve students' achievement to the science concept [10]. When student learn by using animation media, they learn from two cognitive strategies, visual and auditory through the verbal. Animation developed in is the combination of both visual and auditory [11]. 


\section{CONCLUSIONS}

The study results self construction animation in flash program which may allow student to construct the concept of biology, physics and chemistry in the topics of energy, exploding candy, movement and environment. The $\mathrm{N}$ gain of 0.43 proved that the animation can improve students' understanding to the concepts of science and the $t$ test score 2.926 indicated that the students fulfilled mastery learning. Positive responded were given to the animation as it provides appropriate font, interesting graphics and the easiness to construct the concept.

\section{References}

1. Gredler, M.E. (2004). Games and Simulations and their relationships to learning. Handbook of research on educational Communications anf technology $\left(2^{\text {nd }}\right.$ ed). Mahwah, NJ: Lawrence Erlbaum

2. Kemp, J. E.Dayton, D.K. Carraher, R. Szumsku, R.F. (1985) Planning and Producinginstructional Media. New York: J Harper and Row Publishing.

3. Ching-Ting Hsin, Ming-Chaun Li and Chin-Chung Tsai (2014).The Influence of Young Children's Use of Technology on Their Learning: A Review. Journal of Educational Technology \& Society. Volume 17 Number 42014

4. Serban, S. (2010). Use of Animation In Teaching Chemistry. Timisoara: UNIVERSITY "POLITEHNICA" ROMANIA.

5. Tasker, Y., Ed. (2004). A Review of Current Thinking. London: Routledge

6. Munir (2013). Multimedia: Konsep dan Aplikasi dalam Pendidikan. Bandung: Alfabeta Publisher.

7. Barak, M. et al. (2010). Learning Science via Animation Movies: Its effect on students' thinking and motivation. XXX, 1-8. [Online]. Tersedia:http://www.elsevier.com/locate/compedu [diakses tanggal 25 Juni 2015].

8. Rogers, Y. and Scaife, M. (1998). How Can Interactive Multimedia Facilitate Learning? [Online]. Retrieved from http://citeseerx.ist.psu.edu/viewdoc/download?doi=1 0.1.1.467.3717\&rep=rep1\&type=pdf. [Accessed on August 26, 2015].

9. Nusir. et al. (2012). Studying the Impact of Using Multimedia Interactive Programs at Children Ability to Learn Basic Math Skills. 5 (2), 17 - 32 [Online].Tersedia http://www.researchgate.net/publication/275684942. [Accessed on 26 August 2015].

10. Aremu, A. dan Sangodoyin, A. Computer Animation and the Academic Achievement of Nigerian Senior Secondary School Students in Biology. 6 (2), 148 161.http://www.rcetj.org/index.php/rcetj/article/ [Accessed on 26 August 2015].
11. Mayer, R., \& Moreno, R. (2002). Aids to computerbased multimedia learning. Learning and Instruction, 12(1), 107-119. 